Gowlaun Member of the Lettergesh Formation (in terms of older usage: the Upper Owenduff Group). $115 \mathrm{~m}$ stratigraphically above the top of locality 2 are a few $\mathrm{cm}$ of graptolitic mudstone between coarser greywackes (locality 1, Fig 1) which yielded rare specimens of Retiolites geinitzianus geinitzianus (Barrande). The upper limit of this species in Britain is, so far as the writer is aware, about the top of the centrifugus Zone (Wenlock). Thus the lowest part of the Lettergesh Formation, above the Benbeg mudstone unit, is not older than upper crenulata Zone or younger than basal Wenlock. This broadly agrees with the observations of Rickards \& Smyth (1968) who recorded a murchisoni Zone fauna from low in the Lettergesh Formation near Clonbur, although at that locality the base of the formation was not seen.

Thus the marine red beds of the Howgill Fells, Cross Fells, and Kilbride Peninsula are not only of similar thickness and lithology but are at least approximately the same age.

I am indebted to Dr D. Palmer, Dr B. Lock and others for assistance in collecting the Irish locality, and Miss H. Barton and Miss V. Moreton for similar help with the Howgill Fells locality.

\title{
References
}

Burgess, I. C., Rickards, R. B. \& Strachan, I. 1970. The Silurian strata of the Cross Fell area. Bull. geol. Surv. G.B. 32, 167-82.

Cocks, L. R. M., Holland, C. H., Rickards, R. B. \& Strachan, I. 1971. A correlation of Silurian rocks in the British Isles. $J /$ geol. Soc. Lond. 127, 103-36.

Piper, D. J. W. 1972. Sedimentary environments and palaeogeography of the late Llandovery and earliest Wenlock of North Connemara, Ireland. Jl geol. Soc. Lond. 128, 33-51.

Rickards, R. B. 1964. The Graptolitic Mudstones and Associated Facies in the Silurian Strata of the Howgill Fells. Geol. Mag. 101, 435-51.

1967. The Wenlock and Ludlow succession in the Howgill Fells (north-west Yorkshire and Westmorland). Q. Jl geol. Soc. Lond. 123, 215-51.

1970. The Llandovery (Silurian) Graptolites of the Howgill Fells, Northern England. Palaeontr. Soc. (Monogr.) 123, 1-108.

Rickards, R. B. \& Smyth, W. R. 1968. The Silurian graptolites of Mayo and Galway. Sci. Proc. R. Dubl. Soc. Ser. A, 3, 129-35.

Sedgwick Museum

R. B. RICKARDS

Cambridge CB2 3EQ

20th October 1972

\section{From the Natural Environment Research Council}

SIR, Geochemical Maps-The first of a series of geochemical maps at a scale of $\frac{1}{1}$ in. to 1 mile, based essentially on stream-sediment analyses, was placed on open file at Geochemical Division, 64-78 Gray's Inn Road, London WC1X 8NG, on the 11 September 1972. Copies are also available for consultation at the IGS offices in Edinburgh and Leeds. The map covers Sheet 6, Caithness (Central and Eastern) and part of Sheet 5, Sutherland and parts of Caithness, Ross and Cromarty, of the Geological Survey of Great Britain (Scotland) quarter inch geological map series. The area is also represented by Sheets 102, 103, 109, 110, 116 and the eastern part of Sheet 115 of the 1 in. to 1 mile geological maps of Scotland.

The geochemical data are unsmoothed and presented as proportional symbols at each sampling point, the minimum mean sample density being one sample per $2 \mathrm{~km}^{2}$. The distribution of the following elements is shown: 
Beryllium

Boron

Titanium

Vanadium

Chromium

Manganese

Iron

Cobalt

Nickel

Copper
Zinc

Strontium

Zirconium

Molybdenum

Tin

Barium

Lead

Uranium (stream sediment)

Uranium (water)

The maps are available for inspection at the Geochemical Division by appointment through the Chief Geochemist.

Institute of Geological Sciences

S. H. U. BOWIE

Geochemical Division

64-78 Grays Inn Road

London WC1X 8NG

Tel: 01-242 4531

31 st August 1972

\section{A Mediterranean catastrophe}

SIR,-Most geologists develop early in their training a healthy scepticism towards theories involving catastrophe. A current hypothesis invokes a violent and almost instantaneous flooding of a desiccated low-lying Mediterranean basin with oceanic waters at the beginning of Pliocene time. Properly, this theory has become the subject of fierce controversy.

It was first, I believe, clearly stated by Ruggieri $(1962,1967)$ who claimed that the whole Mediterranean became landlocked towards the close of Miocene time, and dried out to give rise to the evaporites which form the Gessoso-Solfifera Formation in Italy and similar deposits elsewhere.

In Sicily, the Miocene Gessoso-Solffera is overlain by the Trubi Marls of Pliocene age and these marls contain planktonic foraminifera and psychrospheric ostracods which indicate cold, deep water directly open to the ocean (Benson \& Sylvester-Bradley, 1971).

Ruggieri's hypothesis, fantastic as it seems, has been greatly strengthened by the findings made during the Glomar-Challenger cruise in the Mediterranean. Cores have revealed thick Miocene evaporites in all the deep basins, east and west. These are overlain by oceanic sediments closely comparable to the Trubi Marls. And the evaporites in the Red Sea seem to tell the same story.

Two parts of Ruggieri's hypothesis are particularly controversial and these can be explained in other ways. The first alternative claims that the so-called evaporites do not indicate desiccation, but were deposited in submarine conditions. The second claims that the Pliocene transgression was not, by any manner of means, instantaneous, the marine deposits overlying the evaporites being of different ages in different parts of the Mediterranean.

The issues are clear-cut but lack documentation. May I please appeal to those who know the sections to place them on record. It should be perfectly possible to mount an impartial investigation which would resolve the issue. This is especially important in Italy, where directly contrary claims have been made. If the catastrophists are right:

1. The upper levels of the Gessoso-Solfifera should yield a shallow-water euryhaline fauna characterized by such species as the ostracod Cyprideis pannonica.

2. The lowest beds of the marine cover should everywhere yield fossils of the same zone.

If the catastrophists are wrong, the evaporites should contain a marine fauna, and the overlying beds should vary in age and facies. 